Izolan, Ana Maria. A (im)possibilidade de existência de inconstitucionalidade das normas constitucionais originárias - a necessidade de uma releitura da posição brasileira atual. Revista Eletrônica Direito e Política, Programa de Pós-Graduação Stricto Sensu em Ciência Jurídica da UNIVALI, Itajaí, v.13, n.3, $3^{\circ}$ quadrimestre de 2018. Disponível em: www.univali.br/direitoepolitica - ISSN 1980-7791

\title{
A (IM)POSSIBILIDADE DE EXISTÊNCIA DE INCONSTITUCIONALIDADE DAS NORMAS CONSTITUCIONAIS ORIGINÁRIAS - A NECESSIDADE DE UMA RELEITURA DA POSIÇÃO BRASILEIRA ATUAL
}

\author{
THE (IM) POSSIBILITY OF EXISTENCE OF UNCONSTITUTIONALITY OF \\ ORIGINATING CONSTITUTIONAL RULES - THE NEED FOR A RELEASE OF \\ CURRENT BRAZILIAN POSITION
}

Ana Maria Izolan'

SUMÁRIO: Introdução; 1 A Tese de Otto Bachof; 2 A rejeição da tese no ordenamento brasileiro; 3 A implícita modificação do posicionamento do Supremo Tribunal Federal; Considerações finais; Referências das fontes citadas.

\section{RESUMO}

O presente trabalho visa verificar a possibilidade de se encontrar no corpo de uma Constituição normas originárias eivadas pela inconstitucionalidade. Partindo da tese da inconstitucionalidade das normas constitucionais originárias através das ideias formuladas pelo jurista alemão Otto Bachof, autor da Monografia "Normas Constitucionais Inconstitucionais?", este trabalho compara as posições doutrinárias a respeito da possibilidade de existência no ordenamento pátrio daquela tese, contrastando as considerações dos doutrinadores nacionais e internacionais frente às decisões do STF. Busca também analisar a rigidez desse posicionamento frente ao dinamismo do direito e da evolução da sociedade e suas necessidades, conjugados com a obediência ao princípio da dignidade da pessoa humana, as posições favoráveis e as contrárias a esse modelo, buscando assumir ao final um posicionamento definido. O aprofundamento do tema acontece no desenvolvimento dos pontos: A Tese de Bachof, A rejeição da tese no ordenamento brasileiro e A implícita modificação do posicionamento do STF.

Palavras-chave: normas constitucionais inconstitucionais; possibilidade; hermenêutica constitucional

\section{ABSTRACT}

This study aims to verify the possibility of finding on the body of Constitution original rules tainted by unconstitutional. Basing on the theory of unconstitutional of the original constitutional norms through the ideas formulated by the German jurist Otto Bachof, author of the monograph "Unconstitutional Constitutional Norms?", this paper compares the various doctrinal positions about the possible

\footnotetext{
${ }^{1}$ Advogada OAB/RS 79.218. Assessora Jurídica Sênior na Izolan Assessoria Empresarial. Diretora na Izolan \& Advogados Associados - OAB/RS 4964. Pós-graduada em Direito Público com ênfase em Direito Constitucional - UCS/RS. Pós-graduada em Direito Militar - Verbo Jurídico/RS. E-mail: anaizolan@gmail.com
} 
Izolan, Ana Maria. A (im)possibilidade de existência de inconstitucionalidade das normas constitucionais originárias - a necessidade de uma releitura da posição brasileira atual. Revista Eletrônica Direito e Política, Programa de Pós-Graduação Stricto Sensu em Ciência Jurídica da UNIVALI, Itajaí, v.13, n.3, $3^{0}$ quadrimestre de 2018. Disponível em: www.univali.br/direitoepolitica - ISSN 1980-7791

existence in order that parental rights thesis, contrasting considerations of national and international scholars, faced with decisions of the Supreme Court. It also seeks to analyze the stiffness of the dynamic positioning ahead of the law and the evolution of society and its needs, combined with obedience to the principle of human dignity, and the favorable positions contrary to that model, seeking to take a position defined end. The deepening of the theme occurs in the development of points: The Bachof's Thesis, the rejection of the thesis in the Brazilian legal and the implied change in the positioning of the Supreme Court.

Keywords: constitutional standards unconstitutional. Possibility. Constitutional hermeneutics.

\section{INTRODUÇÃO}

A escolha do presente tema tem por base buscar as origens da análise do tema, surgido no ordenamento Alemão, o porquê dessa argumentação e o intuito da sua criação. Visa analisar se há eficácia na utilização deste modelo no ordenamento jurídico brasileiro, especificamente em relação ao controle da constitucionalidade das normas constitucionais originárias em vigor.

Por meio de pesquisa doutrinária e jurisprudencial, buscou-se descobrir se há, na prática, aspectos desta tese que possam, não obstante posicionamento contrário firmado pelo STF, contribuir para identificar a existência de normas constitucionais originalmente postas pelo Legislador Constituinte Originário que possam ser consideradas inconstitucionais ao se contraporem a um suposto constitucionalismo supralegal.

A tese da inconstitucionalidade de normas originalmente constitucionais vem ganhando relevância, de tempos em tempos, no ordenamento nacional não apenas pelo fato de soar como uma contradição lógica a sua própria existência, mas também por conta do reposicionamento dos Tribunais frente às reinventadas formas de interpretação constitucional.

Ainda, tal controvérsia passa a ser sujeita a maior atenção diante da evolução e dos diferentes enfoques dado aos valores sociais, bem como pelo fortalecimento e aprimoramento do alcance do Princípio da Dignidade da Pessoa Humana. 
Izolan, Ana Maria. A (im)possibilidade de existência de inconstitucionalidade das normas constitucionais originárias - a necessidade de uma releitura da posição brasileira atual. Revista Eletrônica Direito e Política, Programa de Pós-Graduação Stricto Sensu em Ciência Jurídica da UNIVALI, Itajaí, v.13, n.3, $3^{\circ}$ quadrimestre de 2018. Disponível em: www.univali.br/direitoepolitica - ISSN 1980-7791

Acerca deste tema de inconstitucionalidade de normas originárias, ninguém tratou melhor do que o ex-membro do Tribunal Constitucional Alemão, Otto Bachof.

Considerado um dos grandes doutrinadores alemães, foi sujeito da doutrinação nazista e, após superar o conturbado contexto social e político da Segunda Guerra, concebeu sua tese "Normas Constitucionais Inconstitucionais?" (Verfassungswidrige Verfassungsnormen?) em 1951.

Não apenas nacionalmente, mas internacionalmente, diversos autores rechaçaram a tese do citado doutrinador, dentre os quais podemos destacar o ilustre jurista Paulo Bonavides. Não obstante seja um dos maiores constitucionalistas brasileiros, é também um extremo conhecedor do Direito Constitucional Alemão, país onde se originou a tese das normas constitucionais inconstitucionais.

No tocante à análise do tema sob a ótica das Cortes Constitucionais, o Supremo Tribunal Federal decidiu, à unanimidade, em acórdão prolatado face à Adin $\mathrm{n}^{\circ}$ 815-3/DF, relator Ministro Moreira Alves, cuja fundamentação girava em torno do tema aqui tratado, não conhecer essa ação por impossibilidade jurídica do pedido.

Desta forma, inobstante a tese brilhantemente levantada pelo jurista alemão, cumpre salientar que o Supremo Tribunal Federal apenas admite a possibilidade de controle de constitucionalidade em relação ao Poder Constituinte derivado, depreendendo-se, portanto, que as revisões e as emendas devem estar orientadas pelos parâmetros estabelecidos na Carta Magna.

Pelo menos era esse o posicionamento até a edição da Súmula Vinculante 25.

\section{A TEORIA DE OTTO BACHOF}

A principal base teórica utilizada para o desenvolvimento desse estudo é a obra de Otto Bachof - Normas Constitucionais Inconstitucionais? - onde este autor originalmente estuda a tese da possibilidade de se constatarem normas 
Izolan, Ana Maria. A (im)possibilidade de existência de inconstitucionalidade das normas constitucionais originárias - a necessidade de uma releitura da posição brasileira atual. Revista Eletrônica Direito e Política, Programa de Pós-Graduação Stricto Sensu em Ciência Jurídica da UNIVALI, Itajaí, v.13, n.3, $3^{0}$ quadrimestre de 2018. Disponível em: www.univali.br/direitoepolitica - ISSN 1980-7791

constitucionais, dentro do Texto originário da Constituição, que seriam inconstitucionais em face ao Direito Supralegal, permitindo, portanto, a declaração de inconstitucionalidade pelos Tribunais Constitucionais.

Discorrendo sobre um ponto do estudo do Direito Constitucional que permanecia inexplorado até então, qual seja, a eventual existência de hierarquia entre as normas do maior diploma normativo de um ordenamento jurídico, o autor da teoria elaborou questionamento que surpreende pela ousadia científica.

Sua teoria foi desenvolvida após a outorga da Carta Alemã, Lei Fundamental (Grundgesetz) de Bonn (1949). Como é sabido, ela foi produzida sob os augúrios do governo de transição pós-segunda guerra e sem o elemento de legitimação do povo. ${ }^{2}$

Assim, a doutrina de Bachof proclama a existência de condicionamentos da ordem do direito natural perante o próprio campo do direito constitucional positivado na Constituição. Acredita ele, desta forma, na existência de um campo transcendental-valorativo que vem a informar e subverter a interpretação e aplicação das próprias normas jurídicas constitucionais.

Segundo ele, "se uma norma constitucional infringir uma outra norma da constituição, positivadora de direito supralegal, tal norma será, em qualquer caso, contrária ao direito natural". ${ }^{3}$

Não obstante, o autor distingue a inconstitucionalidade de normas constitucionais por contradição com normas constitucionais de grau superior da inconstitucionalidade das normas constitucionais por "infração de direito supralegal positivado na lei constitucional".

\footnotetext{
2 STRECK, Lenio; BARRETO, Vicente de Paulo; OLIVEIRA, Rafael Tomaz. Normas constitucionais inconstitucionais ou Lado B. Disponível em ConJur de 19.07.2009. https://www.conjur.com.br/2009-jul-19/confiar-interpretacao-constituicao-poupa-ativismojudiciario, acesso em 17/09/2012 às 14:35.

3 Normas Constitucionais Inconstitucionais?. Tradução de CARDOSO DA COSTA, pgs. 62/63, Atlântida Editora, Coimbra, 1977.
} 
Izolan, Ana Maria. A (im)possibilidade de existência de inconstitucionalidade das normas constitucionais originárias - a necessidade de uma releitura da posição brasileira atual. Revista Eletrônica Direito e Política, Programa de Pós-Graduação Stricto Sensu em Ciência Jurídica da UNIVALI, Itajaí, v.13, n.3, $3^{\circ}$ quadrimestre de 2018. Disponível em: www.univali.br/direitoepolitica - ISSN 1980-7791

Reconhece que, quanto à primeira dessas duas hipóteses o constituinte originário, por não estar vinculado ao direito suprapositivo, inexistente no caso, tem liberdade para determinar quais sejam essas normas constitucionais de grau superior, podendo, igualmente, estabelecer exceções a elas no próprio dispositivo que a encerra ou em outro, salvo se essas exceções forem

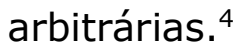

Ainda, refere à inconstitucionalidade por infração de direito constitucional consuetudinário. Dispõe o autor que este direito consuetudinário poderá completar ou até mesmo afastar o direito constitucional. Ressalva que há afastamento do direito constitucional nos casos em que há mudança paulatina no sentido das normas, mesmo sem haver alteração textual. Observe-se que se trata de um típico caso de interferência da hermenêutica na forma de enxergar e aplicar o direito. É como se os sentidos conferidos à norma constitucional fossem sendo gradualmente alterados pelo direito consuetudinário, como ocorre, por exemplo, nas mutações constitucionais. Parafraseando Canotilho, muda o sentido sem mudar o texto. ${ }^{5}$

Transpondo a realidade alemã para o nosso ordenamento, o ensinamento do Prof. Humberto Ávila exemplifica essas questões de ampliação demasiada do sentido da norma, criticando veementemente a posição pacífica do Supremo Tribunal Federal, que, de modo indireto, permite que, a pretexto de concretizar a norma, a praxe altere o seu real sentido:

Compreender 'provisória' como permanente, 'trinta dias' como mais de trinta dias, 'todos os recursos' como alguns recursos, 'ampla defesa' como restrita defesa, 'manifestação concreta da capacidade econômica' como manifestação provável de capacidade econômica, não é concretizar o texto

\footnotetext{
4815 DF, Relator: MOREIRA ALVES, Data de Julgamento: 27/03/1996, TRIBUNAL PLENO, Data de Publicação: DJ 10-05-1996 PP-15131 EMENT VOL-01827-02 PP-00312

5 Artigo NORMAS CONSTITUCIONAIS INCONSTITUCIONAIS? A TEORIA DE OTTO BACHOF, disponível em

http://www.conpedi.org.br/manaus/arquivos/anais/salvador/thais_bandeira_oliveira_passos.pdf. Acesso em 29.08.2012 as 21.14h
} 
Izolan, Ana Maria. A (im)possibilidade de existência de inconstitucionalidade das normas constitucionais originárias - a necessidade de uma releitura da posição brasileira atual. Revista Eletrônica Direito e Política, Programa de Pós-Graduação Stricto Sensu em Ciência Jurídica da UNIVALI, Itajaí, v.13, n.3, $3^{0}$ quadrimestre de 2018. Disponível em: www.univali.br/direitoepolitica - ISSN 1980-7791

constitucional. É, a pretexto de concretizá-lo, menosprezar seus sentidos mínimos. 6

A hipótese em que o ensejo à declaração de inconstitucionalidade de normas constitucionais oriundas do poder constituinte originário realmente toma terreno na obra de Bachof é justamente quando essas normas violarem o direito supralegal, também denominado por este de direito natural. Todavia, tal direito recebe um caráter objetivo pelo teórico:

Queria evitar aqui o mais possível a expressão $<<$ direito natural>>, por causa da sua multifacetada utilização. Quando, por falta de uma palavra igualmente concisa, se falar ocasionalmente, na exposição que vai seguir-se, de normas $<<$ contrárias ao direito natural $>>$, entender-se-á aí o direito natural como autêntico direito supralegal, com pretensão de vigência imediata face aos destinatários das normas, e não simplesmente como um princípio regulativo para o legislador ou como um princípio jurídico fundamental apenas com obrigatoriedade moral. $^{7}$

Deste modo, tentou Bachof, até mesmo para evitar a rejeição doutrinária ao termo direito natural, emprestar-Ihe um caráter objetivo, tratando deste como um verdadeiro direito supralegal, com vigência e não com amparo somente em disposições morais. Somente à violação deste direito supralegal pela Constituição, em norma estatuída pelo poder constituinte originário, poderia levar à declaração de inconstitucionalidade. ${ }^{8}$

\section{CRÍtICA À TEORIA DE BACHOF POR PARTE DO ORDENAMENTO JURÍDICO BRASILEIRO}

A teoria desenvolvida por Otto Bachof tem sido, ao menos explicitamente e no que se refere à hierarquia entre as normas constitucionais, rechaçada pelo constitucionalismo pátrio, por viger o princípio da unidade da Constituição. Entende Luis Roberto Barroso:

\footnotetext{
6 ÁVILA, Humberto. Teoria dos Princípios: da definição à aplicação dos princípios jurídicos. Malheiros Editores, São Paulo, 2004, p. 23.

7 BACHOF, Otto. Normas Constitucionais Inconstitucionais? .Coimbra: Livraria Almedina, 1994. P. 14

8 Artigo A Inconstitucionalidade de normas constitucionais originárias e a ADI 815-3, disponível em http://ojs.idp.edu.br/index.php/observatorio/article/viewFile/233/193
} 
Izolan, Ana Maria. A (im)possibilidade de existência de inconstitucionalidade das normas constitucionais originárias - a necessidade de uma releitura da posição brasileira atual. Revista Eletrônica Direito e Política, Programa de Pós-Graduação Stricto Sensu em Ciência Jurídica da UNIVALI, Itajaí, v.13, n.3, $3^{0}$ quadrimestre de 2018. Disponível em: www.univali.br/direitoepolitica - ISSN 1980-7791

O fundamento subjacente a toda a idéia de unidade hierárquico-normativa da Constituição é o de que as antinomias eventualmente detectadas serão sempre aparentes e, ipso facto, solucionáveis pela busca de um equilíbrio entre as normas, ou pela exclusão da incidência de alguma delas sobre dada hipótese, por haver 0 constituinte disposto neste sentido. ${ }^{9}$

A ideia central do trabalho do professor Otto Bachof encontra guarida na análise do relacionamento vivo que existe entre o direito supralegal, vinculador do constituinte originário, colocando limites a um Poder originariamente ilimitado, com sua obra, a Constituição.

Reconhecendo essa ordem de valores conformadora da Constituição, acrescentase o conhecimento doutrinário do professor Edvaldo Brito, que aduz ao fato de ser:

[...] por causa da necessidade de conformação dessas normas com esses valores que se pode examinar se 0 legislador delas exorbitou, ou não, da sua função que é de potência e não de competência. Ainda que seja, como o é, uma potência, o legislador constituinte não poderá ferir o direito suprapositivo, balizador desse legislador. ${ }^{10}$

É neste sentido que a doutrina alemã fala de normas constitucionais (da Constituição jurídica) inconstitucionais (se ferem valores fundamentais constantes da Constituição essência).

Contudo, é sabido que em todo e qualquer documento constitucional, bem assim em toda e qualquer lei ordinária, haverá preceitos de importância basilar, e outros de menor importância.

A tese doutrinária liderada por Otto Bachof defende a possibilidade de normas originalmente contidas no texto constitucional, mas de significado secundário, serem materialmente inconstitucionais, por violarem preceito material fundamental da constituição.

\footnotetext{
9 BARROSO, Luís Roberto. Interpretação e Aplicação da Constituição. São Paulo: Saraiva, 1996, p. 196.
}

10 BRITO, Edvaldo. Limites da Revisão Constitucional. São Paulo: Sergio Fabris, 1993. p. 35. 
Izolan, Ana Maria. A (im)possibilidade de existência de inconstitucionalidade das normas constitucionais originárias - a necessidade de uma releitura da posição brasileira atual. Revista Eletrônica Direito e Política, Programa de Pós-Graduação Stricto Sensu em Ciência Jurídica da UNIVALI, Itajaí, v.13, n.3, $3^{0}$ quadrimestre de 2018. Disponível em: www.univali.br/direitoepolitica - ISSN 1980-7791

Entretanto, como assinala J.J Gomes Canotilho:

A distinção entre normas material e formalmente constitucionais e normas formal, mas não materialmente constitucionais, mesmo a admitir-se (para, por ex., distinguir o objeto de vários ramos do direito publico), não pode conduzir a uma quebra da unidade normativa da constituição.

Isso significa dizer que todas as normas da constituição tem o mesmo valor, daí derivando ser insustentável a tentativa de supra e infraordenação de normas constitucionais, quer para distinguir entre 'normas constitucionais fortes' e 'normas constitucionais fracas' (Munz), quer para alicerçar a doutrina de normas constitucionais inconstitucionais (Bachof)."

E continuando, a respeito da unidade da constituição aponta que:

o princípio da unidade hierárquico normativa significa que todas as normas contidas numa constituição formal têm igual dignidade (não há normas só formais nem hierarquia se supra-infra-ordenação dentro da lei constitucional). De acordo com esta premissa, só o legislador constituinte tem competência para estabelecer excepções à unidade hierárquico-normativa dos preceitos constitucionais (ex:normas de revisão concebidas como normas superconstitucionais). ${ }^{11}$

Luis Roberto Barroso, no que tange à hierarquia entre normas constitucionais, e reflexamente sobre a inconstitucionalidade das normas originárias frente à outra norma constitucional, afirma que:

com efeito, hierarquia, em Direito, designa o fato de uma norma colher o seu fundamento de validade em outra, sendo inválida se contravier a norma matriz. Ora bem: não é isso que se passa na situação aqui descrita. Pelo principio da unidade da Constituição, inexiste hierarquia entre normas constitucionais originárias, que jamais poderão ser declaradas inconstitucionais umas em face das outras. A proteção especial dada às normas amparadas por cláusulas pétreas sobrelevam seu status político ou sua carga

11 Direito Constitucional e Teoria da Constituição. 7.a Edição - 5.a Reimpressão, Editora Almedina, 2008. Pg.69. 
Izolan, Ana Maria. A (im)possibilidade de existência de inconstitucionalidade das normas constitucionais originárias - a necessidade de uma releitura da posição brasileira atual. Revista Eletrônica Direito e Política, Programa de Pós-Graduação Stricto Sensu em Ciência Jurídica da UNIVALI, Itajaí, v.13, n.3, $3^{0}$ quadrimestre de 2018. Disponível em: www.univali.br/direitoepolitica - ISSN 1980-7791

valorativa, com importantes repercussões hermenêuticas, mas não Ihes atribui superioridade jurídica. ${ }^{12}$

Reconhece-o, sem titubeios, a doutrina nacional:

o direito brasileiro, já foi referido, não admite, como o alemão, a inconstitucionalidade de normas constitucionais, ou seja, de normas incluídas no documento constitucional. Não se admite, entre nós, como na Alemanha, a existência de normas residentes acima da Constituição, determinantes da validade desta, ou residentes na própria constituição, mas porque hierarquicamente superiores, determinante da validade de outras normas constitucionais (...). Vigora entre nós o princípio da unidade hierárquico-normativa Ca Constituição. Ou seja, desde o prisma formal, todas as normas constitucionais residem no mesmo patamar hierárquico ${ }^{13}$

O Supremo Tribunal Federal já firmou, há tempos, sua posição sobre o tema.

AÇÃO DIRETA DE INCONSTITUCIONALIDADE 4097/DF. ADI.Inadmissibilidade. Art. $14, \S 40$, da CF. Norma constitucional originária. Objeto nomológico insuscetível de controle de constitucionalidade. Princípio da unidade hierárquico-normativa e caráter rígido da Constituição brasileira. Doutrina. Precedentes. Carência da ação. Inépcia reconhecida. Indeferimento da petição inicial. Agravo improvido. Não se admite controle concentrado ou difuso de constitucionalidade de normas produzidas pelo poder constituinte originário. $14 \S 4^{\circ} \mathrm{CF} .{ }^{14}$

Destarte, pode-se concluir que o ordenamento jurídico brasileiro não fornece suporte algum à viabilidade da declaração de inconstitucionalidade de norma constitucional constante do texto originário. Ao menos não fornecia.

\section{A IMPLÍCITA MODIFICAÇÃO DO POSICIONAMENTO DO SUPREMO TRIBUNAL FEDERAL}

12 BARROSO, Luís Roberto. Curso de direito constitucional contemporâneo: os conceitos fundamentais e a construção do novo modelo. São Paulo: Saraiva, 2009.Pg. 167

134097 DF, Relator: CEZAR PELUSO, Data de Julgamento: 08/10/2008, Tribunal Pleno, Data de Publicação: DJe-211 DIVULG 06-11-2008 PUBLIC 07-11-2008 EMENT VOL-02340-02 PP-00249.

144097 DF, Relator: CEZAR PELUSO, Data de Julgamento: 08/10/2008, Tribunal Pleno, Data de Publicação: DJe-211 DIVULG 06-11-2008 PUBLIC 07-11-2008 EMENT VOL-02340-02 PP-00249. 
Izolan, Ana Maria. A (im)possibilidade de existência de inconstitucionalidade das normas constitucionais originárias - a necessidade de uma releitura da posição brasileira atual. Revista Eletrônica Direito e Política, Programa de Pós-Graduação Stricto Sensu em Ciência Jurídica da UNIVALI, Itajaí, v.13, n.3, $3^{0}$ quadrimestre de 2018. Disponível em: www.univali.br/direitoepolitica - ISSN 1980-7791

Otto Bachof cita em sua tese a possibilidade de inconstitucionalidade de norma originária resultante da mudança de natureza de normas constitucionais. Seria a cessação da vigência da norma sem disposição expressa.

O raciocínio gira em torno da análise da ausência superveniente dos pressupostos que determinaram o legislador a emitir uma norma jurídica.

No ordenamento brasileiro, tal viés de interpretação assemelha-se ao instituto da mutação constitucional, que, segundo ensina Luis Roberto Barroso:

Consiste em uma alteração do significado de determinada norma da Constituição, sem observância do mecanismo constitucionalmente previsto para emendas e, além disso, sem que tenha havido qualquer alteração de seu texto. Esse novo sentido ou alcance do mandamento constitucional pode decorrer de uma mudança na realidade fática ou de uma nova percepção do direito, uma releitura do que deve ser considerado ético ou justo. ${ }^{15}$

Com relação ao fato concreto, em 2008 o STF reformulou sua interpretação relativamente ao artigo 50, inciso LXVII, para afirmar que a prisão civil se aplicaria somente para os casos de não pagamento voluntário da pensão alimentícia, isentando os casos do depositário infiel, em consonância com o Pacto de São José da Costa Rica (RE 349703, RE 466343 e HC 87585).

Ao operador do direito, dado seu dinamismo, compete a contínua e incansável releitura dos institutos jurídicos frente às readaptações impostas pela sociedade.

Neste diapasão, o entendimento da possibilidade de existência de inconstitucionalidade nas leis constitucionais originárias deveria ser revisto, principalmente diante dos grandes princípios do bem comum, do direito natural, da moral e da razão, afastando-se, assim, a perspectiva rígida de uma "onipotência do poder constituinte" e na linha da consagração do princípio da proibição do retrocesso, adotá-la em relação à proteção máxima dos direitos fundamentais.

15 BARROSO, Luis Roberto Barroso. Curso de direito constitucional contemporâneo; os fundamentos constitucionais e a Constituição do novo modelo. São Paulo: Saraiva. 2009. P.126 
Izolan, Ana Maria. A (im)possibilidade de existência de inconstitucionalidade das normas constitucionais originárias - a necessidade de uma releitura da posição brasileira atual. Revista Eletrônica Direito e Política, Programa de Pós-Graduação Stricto Sensu em Ciência Jurídica da UNIVALI, Itajaí, v.13, n.3, $3^{\circ}$ quadrimestre de 2018. Disponível em: www.univali.br/direitoepolitica - ISSN 1980-7791

Parece que nessa linha andou o próprio Supremo Tribunal Federal ao negar vigência ao artigo 50, inciso LXVII, da CF, e editando a Súmula Vinculante 25.

LXVII - não haverá prisão civil por dívida, salvo a do responsável pelo inadimplemento voluntário e inescusável de obrigação alimentícia e a do depositário infiel;

É ilícita a prisão civil de depositário infiel, qualquer que seja a modalidade do depósito. (Súmula Vinculante 25.)

Embora a Constituição Federal, em seu artigo 50, inciso LXVII, ainda admita a prisão do depositário infiel, o Supremo Tribunal Federal reformulou sua jurisprudência em dezembro de 2008 no sentido de que a prisão civil se aplica somente para os casos de não pagamento voluntário da pensão alimentícia, isentando os casos do depositário infiel. O Pacto de São José também admite a prisão por falta de pagamento de pensão alimentícia.

Em consequência do julgamento que modificou o entendimento da Corte, os ministros revogaram a Súmula 619 do STF, segundo a qual "a prisão do depositário judicial pode ser decretada no próprio processo em que se constituiu o encargo, independentemente da propositura de ação de depósito".

Para isso, fundamentaram a decisão no mais longo e detalhado artigo da Constituição brasileira - o artigo $5^{\circ}$ - que trata dos direitos fundamentais do homem. O conceito está no valor da liberdade, um bem que só pode ser suprimido em casos excepcionalíssimos.

E assim se posiciona o Pretório Excelso:

A subscrição pelo Brasil do Pacto de São José da Costa Rica, limitando a prisão civil por dívida ao descumprimento inescusável de prestação alimentícia, implicou a derrogação das normas estritamente legais referentes à prisão do depositário infiel." (HC 87.585, Rel. Min. Marco Aurélio, julgamento em 3-12-2008, Plenário, DJE de 26-6-2009.) No mesmo sentido: $\mathrm{HC}$ 94.307, Rel. Min. Cezar Peluso, julgamento em 19-2-2009, Plenário, DJE 6-3-2009; HC 92.356, Rel. Min. Ayres Britto, julgamento em 10-22009, Primeira Turma, DJE de 13-3-2009; HC 96.118, Rel. Min. Cármen Lúcia, julgamento em 3-2-2009, Primeira Turma, DJE de 6-3-2009; HC 94.090, Rel. Min. Ricardo 
Izolan, Ana Maria. A (im)possibilidade de existência de inconstitucionalidade das normas constitucionais originárias - a necessidade de uma releitura da posição brasileira atual. Revista Eletrônica Direito e Política, Programa de Pós-Graduação Stricto Sensu em Ciência Jurídica da UNIVALI, Itajaí, v.13, n.3, $3^{0}$ quadrimestre de 2018. Disponível em: www.univali.br/direitoepolitica - ISSN 1980-7791

Lewandowski, julgamento em 16-12-2008, Primeira Turma, DJE de 17-4-2009; HC 95.120, Rel. Min. Eros Grau, julgamento em 11-11-2008, Segunda Turma, DJE de 14-82009; HC 88.240, Rel. Min. Ellen Gracie, julgamento em 710-2008, Segunda Turma, DJE de 24-10-2008. Em sentido contrário: $\mathrm{HC} 72.131$, Rel. $\mathrm{p} / \mathrm{o}$ ac. Min. Moreira Alves, julgamento em 23-11-1995, Plenário, DJ de 10-8-2003.

Habeas corpus. Prisão civil. Depositário judicial. A questão da infidelidade depositária. Convenção Americana dos direitos humanos (...). Hierarquia constitucional dos tratados internacionais de direitos humanos. Pedido deferido. Ilegitimidade jurídica da decretação da prisão civil do depositário infiel. Não mais subsiste, no sistema normativo brasileiro, a prisão civil por infidelidade depositária, independentemente da modalidade de depósito, trate-se de depósito voluntário (convencional) ou cuide-se de depósito necessário, como o é o depósito judicial. Precedentes. (HC 90.450, Rel. Min. Celso de Mello, julgamento em 23-92008, Segunda Turma, DJE de 6-2-2009.)

Com o novo entendimento, o STF adaptou-se não só ao Pacto de São José, como também ao Pacto Internacional sobre Direitos Civis e Políticos da ONU e a Declaração Americana dos Direitos da Pessoa Humana, firmada em 1948, em Bogotá (Colômbia).

O Ministro Cezar Peluso afirmou que a Constituição Federal não deve ter receio quanto aos direitos fundamentais e foi categórico:

[...] o corpo humano, em qualquer hipótese (de dívida) é o mesmo. O valor e a tutela jurídica que ele merece são os mesmos. A modalidade do depósito é irrelevante. A estratégia jurídica para cobrar dívida sobre o corpo humano é um retrocesso ao tempo em que o corpo humano era o 'corpus vilis' (corpo vil), sujeito a qualquer coisa. ${ }^{16}$

Esta posição vai totalmente de encontro àquela uma vez firmada na ADI 815-3 DF tão estudada quando se trata deste tema de inconstitucionalidade de normas constitucionais originárias. Conforme o Ministro Moreira Alves,

[...] não tendo o Supremo Tribunal Federal, como já se salientou, jurisdição para fiscalizar o poder constituinte

16 http://www.stf.jus.br/portal/cms/verNoticiaDetalhe.asp?idConteudo= 116379 
Izolan, Ana Maria. A (im)possibilidade de existência de inconstitucionalidade das normas constitucionais originárias - a necessidade de uma releitura da posição brasileira atual. Revista Eletrônica Direito e Política, Programa de Pós-Graduação Stricto Sensu em Ciência Jurídica da UNIVALI, Itajaí, v.13, n.3, $3^{\circ}$ quadrimestre de 2018. Disponível em: www.univali.br/direitoepolitica - ISSN 1980-7791

originário, não pode ele distinguir as exceções que, em seu entender, sejam razoáveis das que the pareçam desarrazoadas ou arbitrárias, para declarar estas inconstitucionais.

O Relator do Acórdão no HC 90.450, Ministro Celso de Mello, acerca da prisão do depositário infiel, tece suas considerações no sentido de considerar que a Constituição autoriza a prisão do depositário infiel, porém, cabe ao legislador infraconstitucional torná-la possível, "delineando-lhe os requisitos, determinando-Ihe o prazo de duração e definindo-Ihe o rito de sua aplicação" e finaliza dizendo:

Isto é o que permite examinar esse instrumento coativo sob uma perspectiva eminentemente infraconstitucional e consequentemente viabilizadora da análise - que me parece inteiramente pertinente ao caso em questão - das delicadas relações que se estabelecem entre o Direito internacional Público e o Direito interno dos Estados Nacionais.

Não obstante essa tentativa de responsabilizar única e exclusivamente o legislador infraconstitucional pela efetivação da prisão do depositário infiel, referindo, inclusive, a "não-vinculatividade do legislador ordinário às exceções constitucionais que meramente permitem - mas não obrigam - a instituição, pelo Congresso Nacional, da prisão civil", o fato é que, com a internalização do Pacto de São José da Costa Rica, proibindo esta prisão por respeito à Dignidade da Pessoa Humana, aquela norma constitucional, a sua exceção, no caso, que autoriza a prisão do depositário infiel contrasta com a própria proteção constitucional aos direitos individuais, que abarcam o da dignidade da pessoa humana, tornando-se, portanto, inconstitucional.

A controvérsia, para o Supremo, giraria em torno da posição hierárquica que os tratados sobre direitos humanos assumem dentro do ordenamento jurídico brasileiro: supralegal, infralegal ou constitucional.

Existem posições doutrinárias que afirmam que todos os tratados que versam sobre Direitos Humanos têm natureza constitucional. No caso, materialmente constitucional. Porém, alguns podem referir que o fato de o Pacto de são José da Costa Rica não ter sido internalizado conforme rito do $\S 3^{\circ}$ do artigo $5^{\circ}$ da 
Izolan, Ana Maria. A (im)possibilidade de existência de inconstitucionalidade das normas constitucionais originárias - a necessidade de uma releitura da posição brasileira atual. Revista Eletrônica Direito e Política, Programa de Pós-Graduação Stricto Sensu em Ciência Jurídica da UNIVALI, Itajaí, v.13, n.3, $3^{0}$ quadrimestre de 2018. Disponível em: www.univali.br/direitoepolitica - ISSN 1980-7791

Constituição Federal, não o dotaria desta natureza. Aqueles mesmos doutrinadores afirmam que isso apenas afastaria a natureza formalmente constitucional. Resguardando a substancial.

Nesse sentido ensina o professor Celso Lafer:

O novo art. $3^{\circ}$ do art. $5^{\circ}$ pode ser considerado como uma lei interpretativa destinada a encerrar as controvérsias jurisprudenciais e doutrinarias suscitadas pelo art. 20 do art. 50. De acordo com a opinião doutrinária tradicional, uma lei interpretativa nada mais faz do que declarar o que preexiste, ao clarificar a lei existente.

$[\ldots]$

Este me parece ser o caso do novo $\S 3^{\circ}$ do art. $5^{\circ}$.

Com efeito, entendo que os tratados internacionais de direitos humanos anteriores à constituição de 1988, aos quais o Brasil aderiu e que foram validamente promulgados, inserindo-se na ordem jurídica interna, têm a hierarquia de normas constitucionais, pois foram como tais formalmente recepcionados pelo art. $2^{\circ}$ do art. $5^{\circ}$ não só pela referência nele contida aos tratados como também pelo dispositivo que afirma que os direitos e garantias expressos na Constituição não excluem outros decorrentes do regime e dos princípios por ele adotados.

E continua, referindo-se à evolução do direito frente ao reposicionamento dos valores da sociedade, dizendo que "nesse sentido, aponto que a referência aos princípios pressupõe, como foi visto, a expansão axiológica do Direito na perspectiva 'ex parte civium' dos direitos humanos."17

Acontece que, não obstante atribuir a efetividade da prisão do depositário infiel à lei infraconstitucional, o próprio relator daquele acórdão no HC 90.450, Ministro Celso de Mello, mais adiante no seu voto, atribui caráter constitucional aos tratados que versam sobre direitos humanos:

(...) convenceram-me da necessidade de se distinguir, para efeito de definição de sua posição hierárquica em face do

17 A internacionalização dos direitos humanos: Constituição, Racismo e Relações Internacionais, p. 15/18, 2005, Manoele. 
Izolan, Ana Maria. A (im)possibilidade de existência de inconstitucionalidade das normas constitucionais originárias - a necessidade de uma releitura da posição brasileira atual. Revista Eletrônica Direito e Política, Programa de Pós-Graduação Stricto Sensu em Ciência Jurídica da UNIVALI, Itajaí, v.13, n.3, $3^{0}$ quadrimestre de 2018. Disponível em: www.univali.br/direitoepolitica - ISSN 1980-7791

ordenamento positivo interno, entre convenções internacionais sobre direitos humanos (revestidas de 'supralegalidade', como sustenta o eminente ministro Gilmar Mendes, ou impregnadas de natureza constitucional, como eu próprio reconheço $)(\ldots)^{18}$

\section{CONSIDERAÇÕES FINAIS}

Não obstante a posição, até o momento, firme do Supremo, claramente com vistas a não dar azo ao fortalecimento da ideia de inconstitucionalidade de norma constitucional originária, há um grande número de doutrinadores nacionais que afirmam que os tratados internacionais de direitos humanos assumem sim, na ordem positiva interna brasileira, qualificação constitucional, acentuando, ainda, que:

As convenções internacionais em matéria de direitos humanos, celebradas pelo Brasil antes do advento da EC no 45/2004, como ocorre com o Pacto de são José da Costa Rica, revestem-se de caráter materialmente constitucional, compondo, sob tal perspectiva, a noção conceitual de bloco de constitucionalidade. ${ }^{19}$

Com esta classificação, imperioso seria considerar inconstitucional a norma constitucional originária que autoriza a prisão do depositário infiel, por ofensa direta ao Tratado regularmente ratificado pelo Brasil, de caráter materialmente constitucional, que veda tal prática.

Segundo a opinião da doutrinadora Flávia Piovesan:

Reitere-se que, por força do art. 50, $2^{\circ}$, todos os tratados de direitos humanos, independentemente do 'quorum' de sua aprovação, são materialmente constitucionais, compondo o bloco de constitucionalidade.

18 HC 90.450, Rel. Min. Celso de Mello, julgamento em 23-9-2008, Segunda Turma, DJE de 62-2009.

${ }^{19}$ HC 87.585, Rel. Min. Marco Aurélio, julgamento em 3-12-2008, Plenário, DJE de 26-6-2009. 
Izolan, Ana Maria. A (im)possibilidade de existência de inconstitucionalidade das normas constitucionais originárias - a necessidade de uma releitura da posição brasileira atual. Revista Eletrônica Direito e Política, Programa de Pós-Graduação Stricto Sensu em Ciência Jurídica da UNIVALI, Itajaí, v.13, n.3, $3^{0}$ quadrimestre de 2018. Disponível em: www.univali.br/direitoepolitica - ISSN 1980-7791

E assevera:

Não seria razoável sustentar que os tratados de direitos humanos já ratificados fossem recepcionados como lei federal, enquanto os demais adquirissem hierarquia constitucional exclusivamente em virtude de seu 'quorum' de aprovação. A título de exemplo destaque-se que o Brasil é parte da convenção contra a Tortura e outros tratamentos ou Penas cruéis, desumanos ou degradantes desde 1989, estando em vias de ratificar seu protocolo facultativo. Não haveria qualquer razoabilidade se a este último - um tratado complementar e subsidiário ao principal - fosse conferida hierarquia constitucional, e ao instrumento principal fosse conferida hierarquia meramente legal. Tal situação importaria em agudo anacronismo do sistema jurídico, afrontando, ainda, a teoria geral da recepção acolhida no direito brasileiro. ${ }^{20}$

Expressamente, o máximo que até o momento o STF cedeu foi considerar uma certa hierarquia valorativa de normas constitucionais. Nunca hierarquia jurídica.

No entanto, independentemente dessa posição rígida contra a teoria de Bachof, as decisões da Suprema Corte brasileira têm demonstrado o inverso, compreendendo que determinadas normas constitucionais, por mais claras que sejam, devem se afastadas em face de princípios maiores e consagrados universalmente pelo direito natural.

Não apenas o citado caso, mas também no julgamento das ADI 4277 e ADPF 132, onde o STF reconheceu a união estável e a entidade familiar com relação a pessoas do mesmo sexo, ou quando julgou a ADPF 54 (aborto de anencéfalos) ou a possibilidade de perda do mandato parlamentar por decisão do próprio STF (Ação Penal 470), em contraponto ao disposto no art. 15, III e art. 55, VI, §20, da $\mathrm{CF} / 88$.

Assim, em análise, demonstra-se que a evolução das relações em sociedade e o respeito pela dignidade da pessoa humana, pela importância que estão adquirindo frente aos ordenamentos das diversas nações, conjugada com a legitimidade que possuem, têm sido dotadas, reflexamente, do condão de

20 Direitos Humanos e o Direito Constitucional Internacional, p. 51/77, 7a Ed., 2006, Saraiva. 
Izolan, Ana Maria. A (im)possibilidade de existência de inconstitucionalidade das normas constitucionais originárias - a necessidade de uma releitura da posição brasileira atual. Revista Eletrônica Direito e Política, Programa de Pós-Graduação Stricto Sensu em Ciência Jurídica da UNIVALI, Itajaí, v.13, n.3, $3^{0}$ quadrimestre de 2018. Disponível em: www.univali.br/direitoepolitica - ISSN 1980-7791

levantar um questionamento sobre a possibilidade de se flexibilizar a inexistência de normas constitucionais originárias inconstitucionais.

\section{REFERÊNCIA DAS FONTES CITADAS}

ÁVILA, Humberto. Teoria dos Princípios: da definição à aplicação dos princípios jurídicos. Malheiros Editores, São Paulo, 2004.

BACHOF, Otto. Normas Constitucionais Inconstitucionais? Trad. e nota prévia de José Manuel M. Cardoso da Costa. Coimbra: Almedina, 1994.

BARROSO, Luis Roberto. Interpretação e Aplicação da Constituição. São Paulo: Saraiva, 1996.

Curso de Direito Constitucional. São Paulo:Saraiva, 2009.

BOBBIO, Norberto. Teoria do Ordenamento Jurídico. 6. ed. Brasília: UnB, 1995.

BONAVIDES, Paulo. Ciência Política. 10. ed. São Paulo: Malheiros, 1996.

Curso de Direito Constitucional. 7. ed. São Paulo: Malheiros, 1997.

BRITO, Edvaldo. Limites da Revisão Constitucional. São Paulo: Sergio Fabris, 1993.

CANOTILHO, J.J. Gomes. Direito Constitucional e Teoria da Constituição. 7. a Edição - 5. a Reimpressão, Editora Almedina, 2008.

ESTRELLA, André Luiz Carvalho. Normas constitucionais inconstitucionais (Verfassungswidrige Verfassungsnormen). Jus Navigandi, Teresina, a. 8, n. 268, 1 abr. 2004. Disponível em: <http://www1.jus.com.br/doutrina/texto.asp?id=5021>. Acesso em: 02 set. 2012.

FURASTÉ, Pedro Augusto. Normas técnicas para o trabalho científico.14ed. Porto Alegre: Brasil, 2006.

LAFER, Celso. A internacionalização dos direitos humanos: Constituição, racismo e relações internacionais. São Paulo: Manole, 2005.

PASSOS,Thaís Bandeira Oliveira. PESSANHA, Vanessa Vieira. NORMAS CONSTITUCIONAIS INCONSTITUCIONAIS? A TEORIA DE OTTO BACHOF. Disponível em: http://www.conpedi.org.br/manaus/arquivos/anais/salvador/thais_bandeira_oliv eira_passos.pdf. Acesso em 29 ago. 2012. 
Izolan, Ana Maria. A (im)possibilidade de existência de inconstitucionalidade das normas constitucionais originárias - a necessidade de uma releitura da posição brasileira atual. Revista Eletrônica Direito e Política, Programa de Pós-Graduação Stricto Sensu em Ciência Jurídica da UNIVALI, Itajaí, v.13, n.3, $3^{0}$ quadrimestre de 2018. Disponível em: www.univali.br/direitoepolitica - ISSN 1980-7791

PIOVESAN, Flávia. Direitos Humanos e o Direito Constitucional Internacional. 7. ed. rev. ampl. e atual. São Paulo: Saraiva, 2006.

POGLIESE, Marcelo Weick. Possibilidade da existência de normas constitucionais inconstitucionais. Disponível em: <www1.jus.com.br/doutrina/texto.asp?id=115>. Acesso em: 01 set. 2012.

SILVA, José Afonso da. Curso de Direito Constitucional Positivo. 14. ed. São Paulo: Malheiros, 1997.

STRECK, Lenio; BARRETO, Vicente de Paulo; OLIVEIRA, Rafael Tomaz. Normas constitucionais inconstitucionais ou Lado B. Disponível em ConJur de 19.07.2009. https://www.conjur.com.br/2009-jul-19/confiar-interpretacaoconstituicao-poupa-ativismo-judiciario. Acesso em: 17 set. 2012.

FERNANDES, Leonardo. A INCONSTITUCIONALIDADE DE NORMAS CONSTITUCIONAIS ORIGINÁRIAS E A ADI 815-3. Disponível em: http://ojs.idp.edu.br/index.php/observatorio/article/viewFile/233/193. Acesso em 29 ago. 2012.

HC 90.450, Rel. Min. Celso de Mello, julgamento em 23-9-2008, Segunda Turma, DJE de 6-2-2009.

Recebido em: 24/09/2018

Aprovado em: 01/11/2018 